\title{
Impact of cyclonic eddies and typhoons on biogeochemistry in the oligotrophic ocean based on biogeochemical/physical/ meteorological time-series at station KEO
}

\author{
Makio C. Honda ${ }^{1 *}$, Yoshikazu Sasai ${ }^{1}$, Eko Siswanto ${ }^{1}$, Akira Kuwano-Yoshida ${ }^{2}$, Hidenori Aiki ${ }^{3}$ and Meghan F. Cronin ${ }^{4}$
}

\begin{abstract}
In 2014, a sediment trap mooring was deployed adjacent to station Kuroshio Extension Observatory (KEO)'s National Ocean and Atmosphere Administration (NOAA) surface mooring. These data, from July 2014 to July 2016, are used here to investigate nutrient supply mechanisms that support ocean productivity in this oligotrophic region of the subtropical western North Pacific. Both years of sediment trap data show that biogenic material fluxes at $\sim 5000 \mathrm{~m}$ increased between late winter (March) and late spring (June). Based on sea surface temperature and upper ocean water temperature profiles, from the NOAA surface buoy, and satellite-based surface chlorophyll- $a$, this increase was likely due to an increase of ocean productivity in early spring (March) that was supported by nutrients supplied by winter mixing. On the other hand, biogenic material fluxes also increased in October 2014, and between late December 2014 and January 2015 when concentrations of nutrients near the surface typically are low. Sea surface height anomalies and vertical profiles of water temperature in the upper $500 \mathrm{~m}$ showed cyclonic eddies passing station KEO and causing upwelling in late July-early August 2014 and November 2014. It appears that these events supplied nutrients to the upper layer, which then caused ocean productivity in the subsurface layer to temporally increase, resulting in increased deep biogenic material fluxes in autumn and winter. This interpretation of the data is consistent with a simple 3D physical-biological model simulation that shows meso-scale cyclonic eddies can supply nutrient to support new production at KEO. During the 2-year-long sediment trap deployments, several typhoons also passed near station KEO and near-inertial internal waves were observed near the nitracline depth after the typhoons passed. Although turbulent mixing caused by near-inertial internal wave could have possibly supplied nutrient to upper oligotrophic euphotic layer, numerical simulations of the turbulent nutrient supply indicate that enhanced turbulent diffusion across the nutrient concentration gradient did not supply enough nitrate to support the increase in biogenic material flux in autumn.
\end{abstract}

Keywords: KEO, Oligotrophic, Carbon hot spot, Sediment trap, Cyclonic eddy, Nutrient, Typhoon, OceanSITES

\section{Introduction}

Recent increases of atmospheric $\mathrm{CO}_{2}$ and associated global warming have caused warming, stratification, deoxygenation, and acidification of the ocean, collectively called "multiple stressors" (e.g., Bopp et al. 2013 and references in their paper). There is now great concern that these changes of the ocean environment will affect the

\footnotetext{
* Correspondence: hondam@jamstec.go.jp

'Japan Agency for Marine-Earth Science and Technology (JAMSTEC),

Yokosuka, Kanagawa, Japan

Full list of author information is available at the end of the article
}

ecosystem, carbon cycle, and the ocean's ability to mitigate future increases of atmospheric $\mathrm{CO}_{2}$.

To collect essential baseline data about this ecosystem and its role in the biological pump, and to facilitate predictions of how these material cycles via biological activity may change, a comparative study of the ecosystem and its biogeochemistry was conducted at time-series stations in the western Pacific eutrophic subarctic gyre (station K2: Fig. 1) and oligotrophic subtropical gyre (station S1: Fig. 1). (For details and highlights on the K2S1 project, see special issue of Journal of 


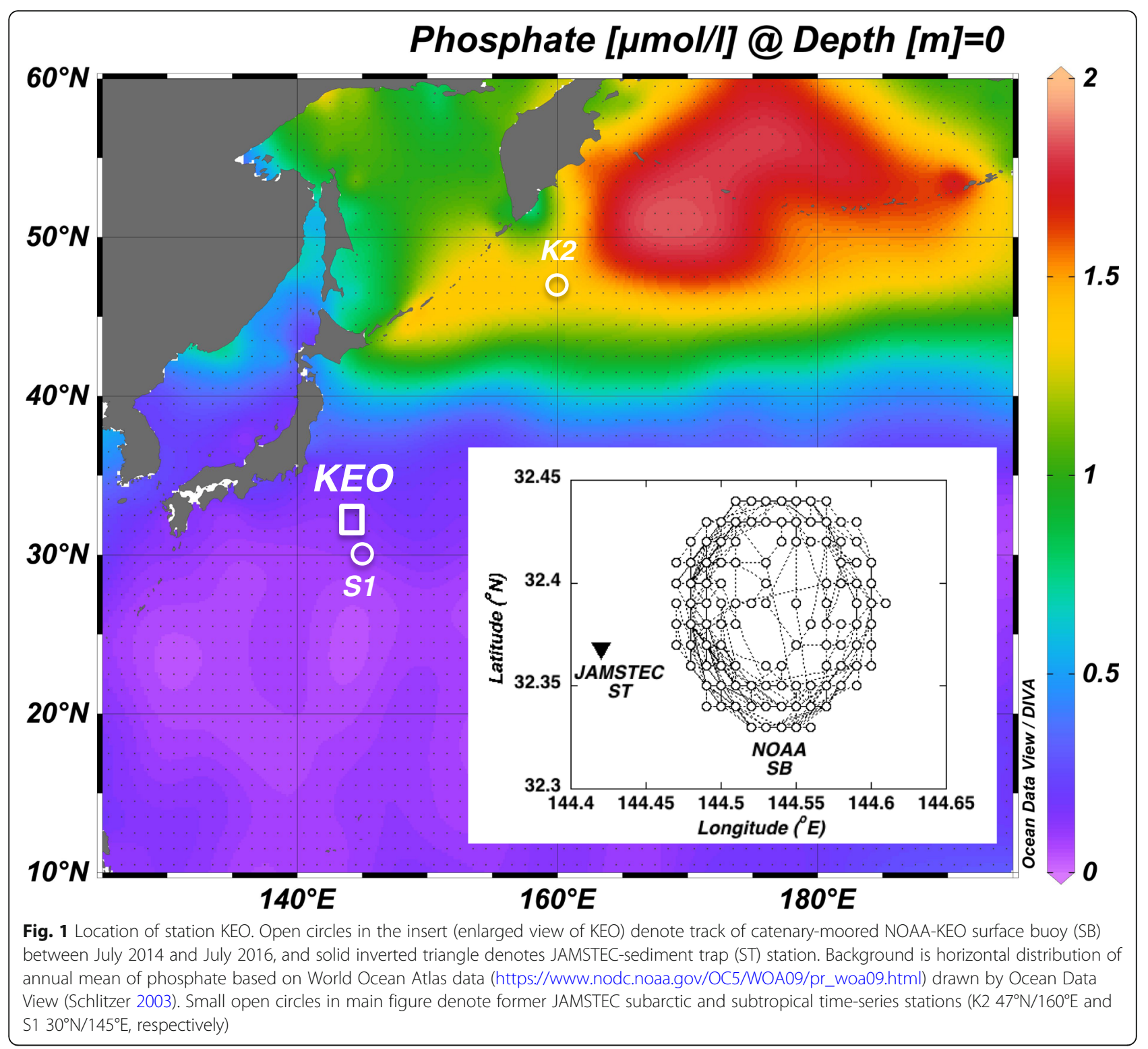

Oceanography vol. 72, no. 3, 2016; Honda et al. 2017). An important finding of this project was that annual mean of phytoplankton biomass and primary productivity at the oligotrophic station S1 were comparable to that at the eutrophic station K2 (Matsumoto et al. 2014, 2016; Honda et al. 2017). Consistent with the K2S1 results, recently, using data from the National Oceanic and Atmospheric Administration (NOAA) Kuroshio Extension Observatory (KEO) surface mooring, Fassbender et al. (2017) estimated the annual net community productivity (aNCP) in the surface mixed layer of oligotrophic North Pacific subtropical region to be $7 \pm$ 3 mol-C m ${ }^{-2}$ year $^{-1}$. This estimate was higher than that in the eutrophic North Pacific subarctic region reported previously $\left(0.5-5\right.$ mol- $\mathrm{C} \mathrm{m}^{-2}$ year ${ }^{-1}$, references in
Fassbender et al. 2017) and, thus, they called the KEO area "the biological hot spot for carbon cycle." Based on chem$\mathrm{ical} /$ physical observations and numerical simulations, several likely "missing nutrient sources" at the oligotrophic station were suggested, including regeneration, meso-scale eddy driven upwelling, meteorological events, and eolian inputs in addition to winter mixing (Sasai et al. 2016).

Understanding vertical motion associated with mesoscale and submesoscale eddies is an area of active research. Cyclonic eddies generally have a shallow thermocline at their center and as these eddies move past a point (e.g., KEO), the subsurface nutricline can temporarily rise into the euphotic zone. As discussed by Martin and Pondaven (2003), eddies can be classified as either "linear" or "non-linear." If the eddy is "linear," the 
nutricline locally rises and falls as the eddy passes, and the local nutricline generally is in the euphotic zone for a short duration. In contrast, if the cyclonic eddy is "non-linear," the uplifted water tends to be trapped in the center of the eddy as it is advected past the local point. In the eddy-rich region of the KEO station, both types of eddies are found: Rossby waves generated by wind anomalies in the central Pacific, as well as non-linear eddies pinched off by large amplitude Kuroshio extension meandering (Qiu 2002). Wind acting on the eddies and eddies forming through a hydrodynamic instability can also have enhanced vertical velocity patterns (McGillicuddy Jr et al. 2007). In addition, Mahadevan et al. (2008) showed that submesoscale dynamics can cause very large vertical velocities along the periphery of the eddies. Effects of meso-scale cyclonic eddies on the supply of nutrients to the surface have been observed with in situ and/or remotely sensed observations at the Bermuda Atlantic Time-series Study (BATS) (McGillicuddy Jr et al. 1998, 2007; Sweeney et al. 2003) and in the Pacific (Sukigara et al. 2014; Inoue and Kouketsu 2016: Kouketsu et al. 2016; Inoue et al. 2016). Sasai et al. (2010) also studied these effects through numerical simulations. In previous studies, the contribution of eddy-induced nutrient to new production were estimated to be from less than $10 \%$ to 100\% (Falkowski et al. 1991: <20\%; McGillicuddy Jr and Robinson 1997: 70\%: McGillicuddy Jr et al. 1998: 40\%: Oschlies and Garcon 1999: 100\%; Siegel et al. 1999: 50\%; Oschlies 2002: < 10\%).

Another mechanism of nutrient supply to the surface sun-lit but oligotrophic layer is meteorologically generated turbulence. Typhoons frequently pass through the NW Pacific subtropical area and, sometimes, near the KEO surface mooring. During the force stage, as the typhoon passes a site, Ekman pumping followed by strong wind- and surface cooling-mixing can lead to a rapid rise of the mixed layer depth followed by mixed layer deepening. Inertial oscillations are also generated preferentially on the right side of the storm, although can occur on the left side if it is transitioning to an extratropical storm (Bond et al. 2011). Convergences and divergences associated with the inertial oscillatory upwelling and downwelling (inertial pumping) after the typhoon has passed. As the oscillations propagate downward into the seasonal thermoclines as near-inertial internal waves, vertical shears can form and cause shear instabilities that result in enhanced turbulent mixing and vertical diapycnal fluxes of nutrients and heat (Inoue et al. 2016). Typhoon-enhanced surface water mixing resulting in ocean productivity has been seen in satellite data (Lin 2012; Lin et al. 2003; Babin et al. 2004; Siswanto et al. 2007, 2008) and numerical simulations (Shibano et al. 2011; Menkes et al. 2016; Pan et al. 2017). Inoue et al.
(2016) showed that typhoon-generated near-inertial internal waves, propagating and breaking in the nutricline led to high export fluxes and high chlorophyll patches in the deep chlorophyll maximum layer. Subsurface nutrient supply and increased productivity have been observed following the passage of typhoon by Zhang et al. (2014) and Rumyantseva et al. (2015). Moreover, another possible nutrient source to the open ocean is eolian dust (Additional file 1). It has been reported that natural and anthropogenic eolian dust includes major/micro-nutrients such as nitrogen and Fe, which can affect ocean biogeochemistry (e.g., Jickells et al. 2005; Duce et al. 2008).

In order to study nutrient supply mechanisms that support ocean productivity in the western North Pacific oligotrophic subtropical region, since July 2014, a deep-sea $(\sim 5000 \mathrm{~m})$ sediment trap mooring has been maintained at station KEO, adjacent to the NOAA surface mooring. The KEO surface mooring has made meteorological and physical oceanographic observations since 2004 and surface carbon measurements since 2006. The meteorological and physical KEO data were used by Cronin et al. $(2013,2015)$ to evaluate the surface heat budget and processes affecting the formation and erosion of the seasonal thermocline. Fassbender et al. (2017) then combined these physical and meteorological time-series with the carbon time-series to describe the mixed layer carbon budgets at KEO, and in particular, the net community production and calcium carbonate production there. Here, we focus on the sediment trap data to relate these physical, meteorological, and biological processes to the biogenic material flux data at $5000 \mathrm{~m}$.

\section{Methods/Experimental Station KEO}

The KEO time-series station in the western Pacific subtropical gyre was established in 2004 by Pacific Marine Environmental Laboratory (PMEL) of NOAA with the deployment of a surface mooring (Fig. 1). One of the primary purposes of the surface mooring has been to measure air-sea heat fluxes. Due to the cold, dry air of continental origin blowing over the warm Kuroshio Extension current, surface heat fluxes out of the ocean in this region are some of the largest found in the basin, a feature that is typical of western boundary current extension (WBCE) regions (Cronin et al. 2008, 2013). As is also characteristic of WBCE regions, meso-scale eddies are very energetic near KEO (e.g., Inoue and Kouketsu 2016). During the warm season, tropical cyclones routinely pass near KEO as they transition to extra-tropical storms (Tomita et al. 2010). In addition, there is large inter-annual and decadal variability in the KEO region that can affect the eddy energy, recirculation gyre size and shape, and Subtropical Mode Water ventilation, all 
of which can affect the biogeochemistry at station KEO (Qiu et al. 2014; Oka et al. 2015).

Based on climatological data from National Institute for Environmental Studies (NIES)-SOOP database (soop.jp), World Ocean Atlas (https://www.nodc.noaa.gov/OC5/ WOA09/pr_woa09.html) and observed data (Japan Agency for Marine-Earth Science and Technology (JAMSTEC) K2S1 database (https://ebcrpa.jamstec.go.jp/k2s1/en/), concentrations of nutrients are quite low in the KEO region compared to the subarctic (Fig. 1), and thus this area can be categorized as oligotrophic.

\section{KEO buoy data}

The KEO NOAA surface mooring (sinker position for 2014-2016: $32^{\circ} 23^{\prime} \mathrm{N} / 144^{\circ} 32^{\prime} \mathrm{E}$ ), has been equipped with various physical and meteorology sensors since 2004 and a suite of carbon sensors since 2006. Multiple CTD (above $525 \mathrm{~m}$ ) and 1-3 current meters (above $36 \mathrm{~m}$ ) on the mooring provided data during experimental period. Data and details of the NOAA surface buoy mooring are available at https:/www.pmel.noaa.gov/ocs/data/disdel/. Although drifting buoy, Argo float, and satellite are often used for time-series analyses, drifter and float data are not Eulerian observations and satellite can observe only sea surface condition. In contrast, this NOAA moored surface buoy provides high-resolution time-series of surface ocean data, and underwater physical oceanographic data, such as upper ocean profile time-series of temperature and density.

\section{Sediment trap experiment and sample chemical analysis}

The sediment trap experiment at KEO began in July 2014 and is ongoing. This study reports on results from the first 2 years, between July 2014 and June 2016, while drawing upon the longer meteorological and physical oceanographic time-series from the adjacent NOAA surface buoy in order to interpret seasonal variability in sediment trap data. A time-series sediment trap (McLane Mark VII-21) with 21 collecting cups was deployed at $32^{\circ} 22^{\prime} \mathrm{N} / 144^{\circ} 25^{\prime} \mathrm{E}$ and about $5000 \mathrm{~m}$ (800 m above seafloor), $\sim 10 \mathrm{~km}$ westward (6 nautical mile) from the NOAA-PMEL KEO buoy. The sediment trap mooring system was initially deployed by R/V Kaiyo in June 2014 and was then turned around by M/V Bluefin in September 2015 and by R/V Shinsei-maru in July 2016. Sampling interval (sampling period per one collecting cup) was 18 days. Before deployment, collecting cups were filled with seawater-based buffered $10 \%$ formalin solution. Non-filtered seawater for this preservative was collected from $2000 \mathrm{~m}$. Its salinity was adjusted to approximately 39 by addition of $\mathrm{NaCl}$ (addition of $50 \mathrm{~g} \mathrm{NaCl}$ to $10 \mathrm{~L}$ of seawater). Initial $\mathrm{pH}$ of this solution was $\sim 8.1$. After recovery of the sediment traps, samples were stored in a refrigerator at $4{ }^{\circ} \mathrm{C}$ until the chemical and biological analysis could be performed at a shore-based laboratory.

After pre-treatment (swimmer elimination, splitting, filtration, drying, weighing for total mass flux, and pulverization) at a shore-based laboratory, the major components of the sinking particles were measured. Concentrations of organic carbon, inorganic carbon and nitrogen were measured with an elemental analyzer (Perkin-Elmer $2400 \mathrm{CHN} / \mathrm{O}$, USA). Concentrations of Al, $\mathrm{Si}, \mathrm{Ca}$, and other trace elements such as $\mathrm{Fe}$ and $\mathrm{Ti}$ were measured with an inductively coupled plasma emission spectrometer (Perkin-Elmer Optima 3300DV, USA). Concentrations of biogenic opal (opal, $\mathrm{SiO}_{2} \cdot 0.4 \mathrm{H}_{2} \mathrm{O}$ ) and $\mathrm{CaCO}_{3}$ were estimated with following equations:

$$
\text { Opal }(\%)=(\mathrm{Si}-3.42 \times \mathrm{Al}) \times 67.2 / 28
$$

$$
\mathrm{CaCO}_{3}(\%)=(\mathrm{Ca}-0.5 \times \mathrm{Al}) \times 100 / 40
$$

where coefficients are based on crustal ratios (Taylor 1964). Honda et al. (2002, 2013) provide further details about pre-treatment and chemical analysis.

\section{Numerical simulation of eddy-induced nutrient supply}

In order to evaluate the effect of cyclonic eddies on biogeochemistry semi-quantitatively, eddy-induced increase of nitrate concentration in the upper $100 \mathrm{~m}$ were estimated between 2000 and 2012 using an eddy-resolving coupled physical-biological model of the North Pacific Ocean. In particular, we used the Ocean general circulation model For the Earth Simulator (OFES) with sea-ice process (Masumoto et al. 2004; Komori et al. 2005) coupled to a simple nitrogen-based Nitrate-Phytoplankton-Zooplankton-Detritus (NPZD) pelagic model (Oschilies 2001). The OFES domain extends from $20^{\circ} \mathrm{S}$ in the south Pacific to $66^{\circ} \mathrm{N}$ in the North Pacific Ocean and from $100^{\circ} \mathrm{E}$ to $70^{\circ} \mathrm{W}$. The eddy-resolving model is $1 / 10^{\circ}$ and has 54 vertical levels from $5 \mathrm{~m}$ thickness at the surface to $330 \mathrm{~m}$ thickness at the maximum depth of $6065 \mathrm{~m}$. The OFES was integrated for 30 years under climatological forcing using the Japanese 25-year Reanalysis (JRA25) (Onogi et al. 2007), from the observed climatological fields of temperature and salinity fields (WOA09: https://www.nodc.noaa.gov/OC5/WOA09/pr_woa09.html) without motion. After 30 years of spin-up integration, the OFES was integrated from 1979 to 2012 using 6-hourly JRA25. Detail of the biological model is described elsewhere (Sasai et al. 2007, 2010). To reach equilibrated biological fields, the biological model was incorporated after 30 years spin-up of the OFES with JRA25 climatological forcing and was integrated over a 5-year period with the climatological forcing. The biological fields at the end of the 5 years were 
then used as the initial condition for the physical-biological model, driven by the JRA25 from 1995 to 2012 .

\section{Results and discussion}

\section{Seasonal variability in materials' flux}

Over the experimental period, averages of biogenic material fluxes at KEO and their standard deviations (organic carbon $2.2 \pm 1.3$; opal $12.8 \pm 12.2 ; \mathrm{CaCO}_{3} 14.6 \pm 8.5 \mathrm{mg} \mathrm{m}^{-2}$ day ${ }^{-1}$; Fig. 2) are comparable to those at $\mathrm{S} 1$ (organic carbon $2.3 \pm$ 0.7; opal 7.0 $\pm 2.9 ; \mathrm{CaCO}_{3} 20.4 \pm 6.1 \mathrm{mg} \mathrm{m}^{-2}$ day $^{-1}$; $\mathrm{K} 2 \mathrm{~S} 1$ database). On the other hand, fluxes at KEO are significantly smaller than that at $\mathrm{K} 2$ (organic carbon $5.5 \pm 1.6$; opal $80.7 \pm$ 36.2; $\mathrm{CaCO}_{3} 38.5 \pm 8.6 \mathrm{mg} \mathrm{m}^{-2}$ day $^{-1}$; $\mathrm{K} 2 \mathrm{~S} 1$ database), while primary productivity at stations $\mathrm{K} 2$ and $\mathrm{S} 1$ were, interestingly, comparable (Matsumoto et al. 2014, 2016; Honda et al. 2017). The cause of larger vertical attenuation in biogenic settling particle in the subtropical region (such as station KEO or S1) than the subarctic region (such as station K2) is still under debate (e.g., Honda and Watanabe 2010).

During the first year (July 2014-July 2015), remarkably large increases in total mass flux (TMF), which were more than $40 \%$ larger than TMF in the preceding and subsequent samples, were observed three times: early October 2014, late December 2014-early January 2015, and late April 2015 (Fig. 2a). During the second year (September 2015-June 2016), although its intensity was
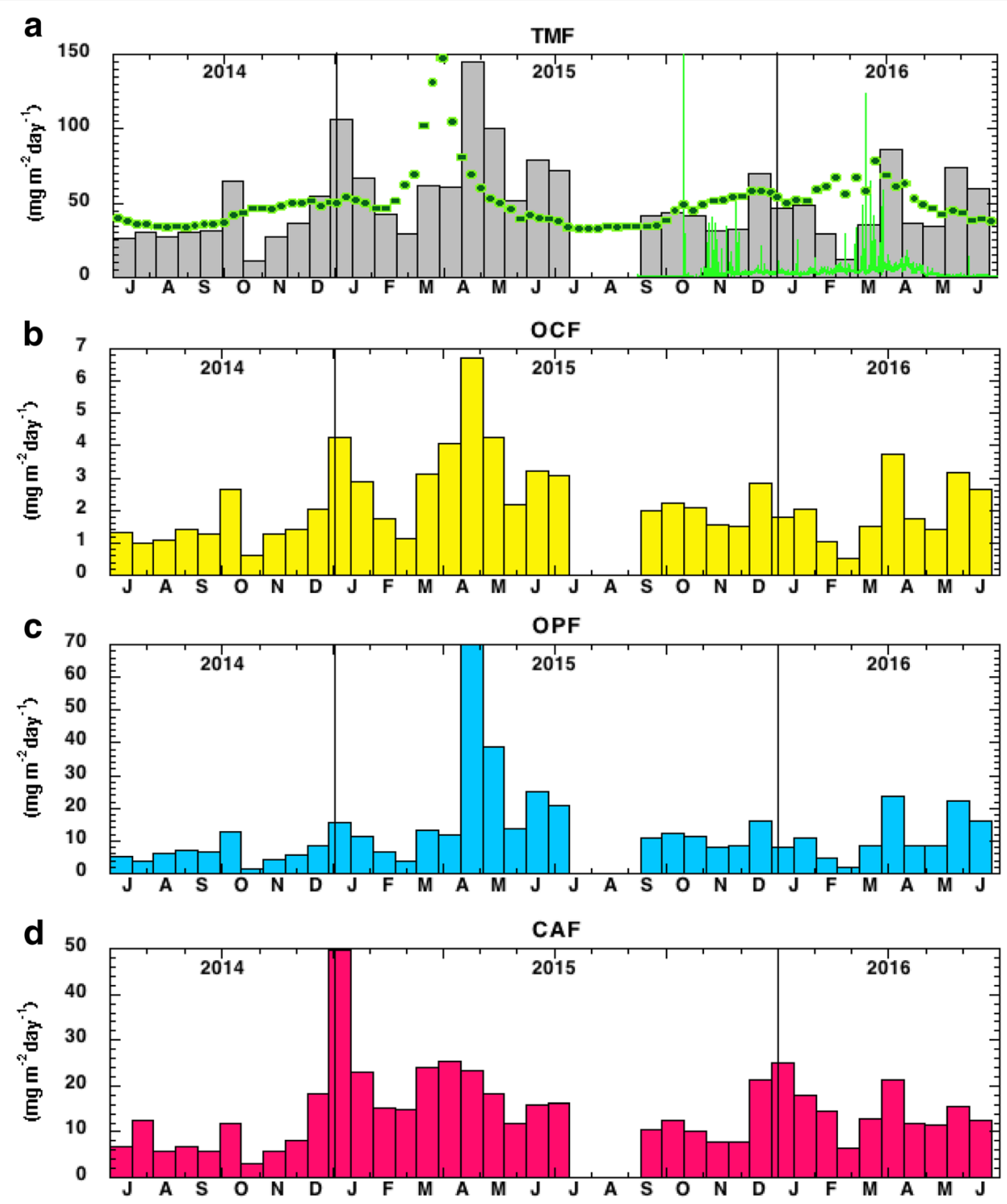

Fig. 2 Seasonal variability in fluxes of total mass (a TMF), organic carbon (b OCF), biogenic opal (c OPF), and $\mathrm{CaCO}_{3}$ (d CAF) at $5000 \mathrm{~m}$ of KEO (bar graphs). Solid circles and yellow-green line graph in a TMF denote index of satellite-based surface Chl-a (8 days composite) and subsurface Chl-a (at about 35 m) observed between September 2015 and June 2016, respectively. Surface Chl- $a$ with 4 km and 8-day spatiotemporal resolutions derived from the moderate resolution imaging spectroradiometer were processed by the NASA's Ocean Biology Processing Group at Goddard Space Flight Center 
not as large as in the first year, TMF was increased two times during almost the same seasons as the first year: middle December 2015 and late March-the first half of April 2016. Average and seasonal variability (standard deviation of seasonal flux) of TMF between September and June in the first year $\left(60.7 \pm 34.2 \mathrm{mg} \mathrm{m}^{-2}\right.$ day $\left.^{-1}\right)$ were slightly but significantly higher than that in the same period of the second year $\left(45.3 \pm 18.9 \mathrm{mg} \mathrm{m}^{-2}\right.$ day $\left.^{-1}\right)$ $(p<0.05, F$ test).

Satellite-based surface chlorophyll-a concentration (Chl-a) started to increase substantially in late February and peaked in late March in both years (Fig. 2a). If it can be assumed that the sinking velocity of particulate materials in the deep sea $(>1000 \mathrm{~m})$ is $100-200 \mathrm{~m} \mathrm{day}^{-1}$ (Honda et al. 2009 and references therein), then peaks of TMF at about $5000 \mathrm{~m}$ in late April 2014 (the first half of April 2015) may reflect this Chl- $a$ increase, i.e., phytoplankton increase in the surface sun-lit layer. On the other hand, not all TMF peaks synchronize with increase of surface Chl- $a$. However, subsurface Chl- $a$ and backscatter at about $35 \mathrm{~m}$ observed in the second year by a fluorometer/backscatter meter package (Satlantic Eco-Triplet, Canada) installed on the KEO buoy mooring line increased in not only March 2016 but also November 2015 (Fig. 2a). Backscatter observed with this sensor also increased simultaneously with Chl-a (data not shown). The observed time-series and numerical simulation of vertical profile of Chl- $a$ at the subtropical time-series station S1 (K2S1 project, Honda et al. 2017) showed occurrence of subsurface Chl- $a$ increase or subsurface Chl- $a$ maximum (SCM) in summer and autumn (Fujiki personal communication 2017; Inoue et al. 2016; Sasai et al. 2016). Thus, it can be presumed that the TMF increase observed in December 2015 reflected this subsurface phytoplankton increase in November 2015.

Seasonal variability in organic carbon flux (OCF) was similar to that of TMF (Fig. 2b) and OCF correlated well with TMF $\left(r^{2}=0.97\right)$. Biogenic opal flux (OPF) also showed similar seasonal variability to TMF $\left(r^{2}=0.81\right)$ and OCF $\left(r^{2}=0.81\right)$ (Fig. 2c). Increases of OCF in April 2015 and March-April 2016 were likely attributed to increase of diatom and/or plankton with biogenic opal test. On the other hand, correlation coefficients between $\mathrm{CaCO}_{3}$ flux (CAF) and TMF, and between CAF and OCF were slightly lower $\left(r^{2}=0.76\right.$ and 0.71 , respectively) (Fig. 2d). Unlike OPF, peaks of CAF appeared in December 2014-January 2015 and December 2015-January 2016. Thus, winter peak in OCF and CAF was likely attributed to the autumn increase of subsurface phytoplankton with $\mathrm{CaCO}_{3}$ such as coccolithophorids. This seasonal variability in phytoplankton species in the western Pacific subtropical region (station $\mathrm{S} 1$ ) is supported by previous studies (Fujiki et al. 2016).

\section{Cyclonic eddy and its effect on increases of phytoplankton and carbon flux}

Based on NOAA surface buoy data, sea surface temperature (SST) at local noontime (12:00) varied from about 15 to $28{ }^{\circ} \mathrm{C}$ (Fig. 3a). Between January 2015 and April 2015, and between February 2016 and April 2016 winter cooling and mixing caused February subsurface subtropical mode water with low temperature $\left(<19{ }^{\circ} \mathrm{C}\right)$ to outcrop at the surface. As a result of mixing within this very deep surface layer, nutrients were supplied to the oligotrophic surface. When the layer began to re-stratify in spring, phytoplankton increased (spring bloom) in the nutrient-rich shallow surface layer as can be seen by the late March increase of surface Chl- $a$ in Fig. 2a. Sequentially, deep sea biogenic material fluxes (OCF, CAF, and OPF) increased as observed at KEO in April-early May (Fig. 2b-d).

In addition to the deep winter mixing periods described above, shoaling of intermediate water with temperature lower than $15{ }^{\circ} \mathrm{C}$ and density higher than 25.5 (sigma theta) to depth of $\sim 100 \mathrm{~m}$ (pressure of $\sim 100$ dbar) was observed in late July or early August and November in 2014 (Fig. 3a, b). During each of these periods, satellite-based sea surface height anomalies (SSHA) at KEO were remarkably low, with values of about $-50 \mathrm{~cm}$ (Fig. 3a) due to a nearby meso-scale cyclonic eddy (Additional file 2: Figure S1). We hypothesize that these isopycnal shoaling events are caused by cyclonic eddy-induced upwelling, which supplied nutrients to depths of near $100 \mathrm{~m}$ below the surface. Although nutrients were not supplied to the surface, $90-100 \mathrm{~m}$ is still within or at the bottom of the euphotic zone during these periods. As described above, the SCM during summer and winter was observed and numerically simulated for this region. Thus, passage of cyclonic eddies in late July and in November 2014 (hereinafter CE1 and CE2, respectively) might have introduced an increase of subsurface phytoplankton. If so, the TMF increase observed in early October 2014 and in late December 2014-early January 2015 might reflect a subsurface phytoplankton increase not observed by satellite. Based on SSHA and vertical profile of seawater temperature, the cyclonic eddy also passed KEO in late April 2015 and in February 2016. However, these periods were when the seasonal thermocline was very weak or absent, and, thus, it is not clear how these eddies could affect phytoplankton. We further note that the average biogenic materials' flux (sum of OCF, CAF, and OPF) in the first year $\left(35.5 \pm 24.5 \mathrm{mg} \mathrm{m}^{-2}\right.$ year $^{-1}$ for September 2014-June 2015) was significantly higher than that in the second year $\left(27.0 \pm 10.3 \mathrm{mg} \mathrm{m}^{-2}\right.$ year $^{-1}$ for September 2015-June 2016) ( $p<0.005, F$ test). This might also be attributed to not only stronger winter mixing but also more cyclonic eddy passing near KEO in the first year during periods when the seasonal thermocline is present. 


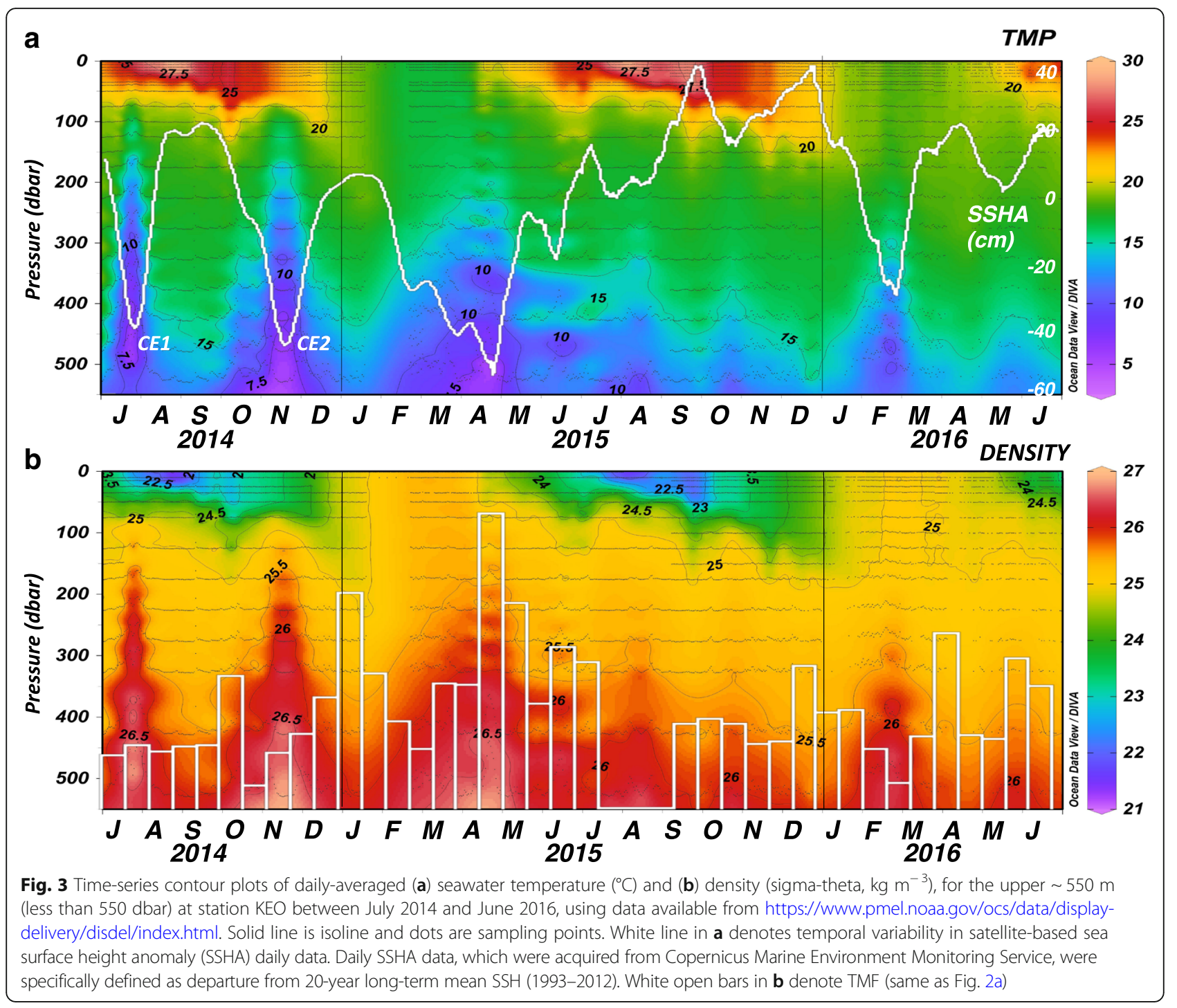

\section{Quantitative evaluation of individual cyclonic eddy as a nutrient supplier}

According to satellite-based SSHA and NOAA buoy data after 2008, cyclonic eddies with SSHA $<-50 \mathrm{~cm}$ typically passed near station KEO a few times (0-3 times) per year (Additional file 3: Figure S2 or Fig. 9 in Fassbender et al. 2017) and, at those times, subsurface water ascended to shallower than $100 \mathrm{~m}$. In order to evaluate the effect of cyclonic eddy on biogeochemistry in more detail, the eddy-induced increase of nitrate concentration in the upper $100 \mathrm{~m}$ (from 100 to $0 \mathrm{~m}$ ) was estimated between 2000 and 2012 using an eddy-resolving coupled physical-biological ocean model (see the "Numerical simulation of eddy-induced nutrient supply" section). The increased integrated nitrate concentration in the upper $100 \mathrm{~m}$ caused by cyclonic eddy with SSHA $<-50 \mathrm{~cm}\left(\Delta_{\text {int }} N_{\text {(eddy) }}\right)$ were estimated by taking the difference of the maximum integrated nitrate concentration in the upper $100 \mathrm{~m}$ when the cyclonic eddy passes KEO from the integrated nitrate concentration in the upper $100 \mathrm{~m}$ just before the cyclonic eddy passes. As shown in Fig. 4, the numerical simulation successfully reproduced the cooling and nutrient enrichment from wintertime mixing, as well as the upwelling of subsurface cold and nutrient rich water to shallower than $100 \mathrm{~m}$ that occurred a few (0-3) times a year when cyclonic eddies with SSHA $<-50 \mathrm{~cm}$ pass near station KEO. Each $\Delta_{\text {int }} N_{\text {(eddy) }}$ and total net of $\Delta_{\text {int }} N_{\text {(eddy) }}$ for respective year (annual $\Delta_{\text {int }} N_{\text {(eddy) }}$ or $\Delta_{\text {int }} \mathrm{AN}_{\text {(eddy) }}$ ) were estimated to be $0.02-1.07$ mol- $\mathrm{N} \mathrm{m}^{-2}$ and 0.10 1.07 mol- $\mathrm{N} \mathrm{m}^{-2}$ year $^{-1}$, respectively (Table 1 ). Between 2000 and 2012, average of $\Delta_{\text {int }} \mathrm{AN}_{\text {(eddy) }}$ (with standard deviation) were estimated to be $0.40 \quad( \pm 0.36)$ mol-N m ${ }^{-2}$ year $^{-1}$. Some eddies passed near KEO during the deep winter mixing (DWM) period. In this case, upwelling of subsurface nutrient-rich water is introduced by 


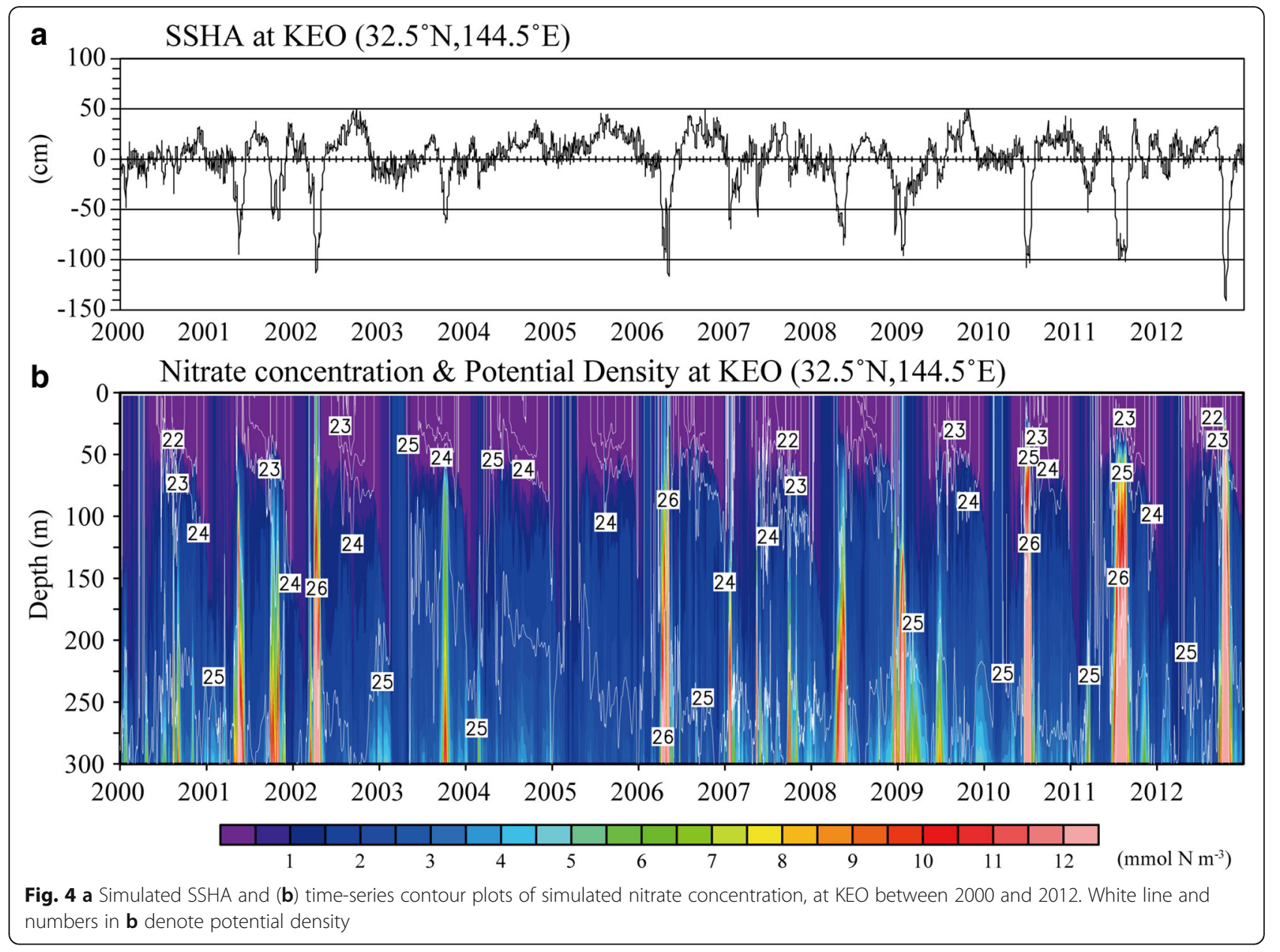

DWM and $\Delta_{\text {int }} N_{\text {(eddy) }}$ might be overestimated. We also calculated $\Delta_{\text {int }} \mathrm{AN}_{\text {(eddy) }}$ without $\Delta_{\text {int }} N_{\text {(eddy) }}$ during the DWM period $\left(0.31 \pm 0.38\right.$ mol- $\mathrm{N} \mathrm{m}^{-2}$ year ${ }^{-1}$, Table 1$)$. This estimate was comparable or slightly higher than that estimated for the Sargasso Sea $\left(0.35\right.$ mol- $\mathrm{N} \mathrm{m}^{-2}$ year $^{-1}$ by McGillicuddy Jr and Robinson 1997, 0.19 mol-N m ${ }^{-2}$ year $^{-1}$ by McGillicuddy Jr et al. 1998, and 0.18 mol- $\mathrm{N} \mathrm{m}^{-2}$ year $^{-1}$ by Siegel et al. 1999).

Next, we attempt to evaluate semi-quantitatively the impact of the CE1 and CE2 eddies on $5000 \mathrm{~m}$ particle flux, recognizing that the variables have large uncertainties, particularly the amount of nutrient $(N)$ supplied to the upper $100 \mathrm{~m}$ by CE1 and CE2, fraction of supplied $N$ utilized by phytoplankton, and fraction of primary productivity (PP) transported vertically to $5000 \mathrm{~m}$. Based on our simulation, a cyclonic eddy with SSHA of $\sim-50 \mathrm{~cm}$, which is comparable in size to CE1 and CE2 (cyclonic eddies 2001-2, 2001-3, 2003-1, 2007-2, 2011-1 in Table 1), can potentially supply nutrient $(N)$ to the upper $100 \mathrm{~m}\left(\Delta_{\text {int }} N_{\text {(eddy) }}\right)$ at a rate of $\sim 0.08$ mol- $\mathrm{N} \mathrm{m}^{-2}$ on average. If supplied $N$ is completely (or 100\%) utilized by phytoplankton, primary productivity can increase by $\sim 0.50$ mol-C $\mathrm{m}^{-2}\left(\mathrm{C} / \mathrm{N}_{(\text {mole })}=6.6\right.$,
Redfield et al. 1963) or $\sim 6.02 \mathrm{~g}-\mathrm{C} \mathrm{m}^{-2}$. Honda et al. (2017) reported that $\sim 0.6 \%$ of PP was transported vertically to $5000 \mathrm{~m}$ at western Pacific subtropical area (S1) as particulate organic carbon at $5000 \mathrm{~m}$ (OCF) on annual average (PP $329 \mathrm{mg}-\mathrm{C} \mathrm{m} \mathrm{m}^{-2}$ day $^{-1}$; OCF $\left.2.0 \mathrm{mg}^{-} \mathrm{C} \mathrm{m}^{-2} \mathrm{day}^{-1}\right)$. If this relation can be applied to PP and OCF at KEO, increase of OCF following increase of PP can be estimated to be $36.6 \mathrm{mg}-\mathrm{C} \mathrm{m} \mathrm{m}^{-2}$. This potential increase is comparable to increases in OCF observed in early

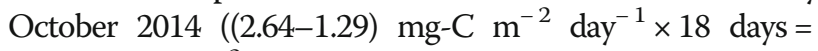
$\left.24.3 \mathrm{mg}^{-\mathrm{C} \mathrm{m}} \mathrm{m}^{-2}\right)$ and in December 2014-January 2015 ((4.27-2.05) $\mathrm{mg}-\mathrm{C} \mathrm{m}^{-2}$ day $^{-1} \times 18$ days $=40.0 \mathrm{mg}-\mathrm{C} \mathrm{m}^{-2}$, Fig. 2b). Thus $\Delta_{\text {int }} N_{\text {(eddy) }}$ can potentially support increase of OCF.

It is noted that if TMF or OCF increase observed in early October 2014 was due to increase of subsurface phytoplankton following an increase in nutrient supplied by CE1 in late July 2014, sinking velocity of the particulate biogenic materials is estimated to be less than $100 \mathrm{~m} \mathrm{day}^{-1}$ (4900 $\mathrm{m} / 60$ days). This sinking velocity is slightly lower than that reported generally $\left(>100 \mathrm{~m} \mathrm{day}^{-1}\right.$, e.g., Honda et al. 2009; Honda et al. 2013). However, it might be conceivable because 
Table 1 Simulated increase of integrated nitrate concentration upper $100 \mathrm{~m}$ by pass of cyclonic eddy with SSHA $<-50 \mathrm{~cm}\left(\Delta_{\text {int }} N_{(\text {eddy) }}\right)$ and annual $\Delta_{\text {int }} N_{\text {(eddy) }}\left(\Delta_{\text {int }} A N_{\text {(eddy) }}\right)$ between 2000 and 2012. $\Delta_{\text {int }} A N_{(e d d y)}$ without winter cooling mixing period (WCM) data are also shown. "O" of $\mathrm{S} / \mathrm{N}$ denotes that no eddy passed over KEO in respective years

\begin{tabular}{|c|c|c|c|c|c|}
\hline Year & $\mathrm{S} / \mathrm{N}$ & Period with SSHA $<-50 \mathrm{~cm}$ & $\begin{array}{l}\Delta_{\text {int }} N_{\text {(eddy) }} \\
\left(\text { mol-N m }{ }^{-2}\right)\end{array}$ & 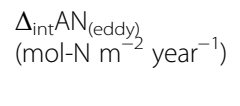 & $\begin{array}{l}\Delta_{\text {int }} A N_{(\text {eddy) }} \\
\left(\text { mol-N m m }^{-2} \text { year }^{-1}\right) \\
\text { without WCM data }\end{array}$ \\
\hline 2000 & 0 & & 0.00 & 0.00 & 0.00 \\
\hline \multirow[t]{3}{*}{2001} & 1 & 11 May-30 May & 0.22 & 0.32 & 0.32 \\
\hline & $2^{\mathrm{a}}$ & 3 October-11 October & 0.08 & & \\
\hline & $3^{a}$ & 10 October-2 November & 0.02 & & \\
\hline 2002 & 1 & 31 March-26 April ${ }^{b}$ & 0.68 & 0.68 & 0.00 \\
\hline 2003 & $1^{\mathrm{a}}$ & 1 October-12 October & 0.10 & 0.10 & 0.10 \\
\hline 2004 & 0 & & 0.00 & 0.00 & 0.00 \\
\hline 2005 & 0 & & 0.00 & 0.00 & 0.00 \\
\hline \multirow[t]{2}{*}{2006} & 1 & 7 April-25 April & 0.36 & 0.99 & 0.99 \\
\hline & 2 & 28 April-11 May & 0.63 & & \\
\hline \multirow[t]{2}{*}{2007} & 1 & 18 January-26 January ${ }^{\text {b }}$ & 0.16 & 0.27 & 0.12 \\
\hline & $2^{\mathrm{a}}$ & 16 May-16 May & 0.12 & & \\
\hline \multirow[t]{2}{*}{2008} & 1 & 16 April-23 May & 0.10 & 0.34 & 0.34 \\
\hline & 2 & 16 December-21 December & 0.24 & & \\
\hline 2009 & 1 & 8 January-30 January ${ }^{\mathrm{a}}$ & 0.33 & 0.33 & 0.00 \\
\hline 2010 & 1 & 20 June-16 July & 0.65 & 0.65 & 0.65 \\
\hline \multirow[t]{2}{*}{2011} & $1^{\mathrm{a}}$ & 13 March-13 March $^{\mathrm{b}}$ & 0.06 & 0.44 & 0.38 \\
\hline & 2 & 9 July-26 August & & & \\
\hline \multirow[t]{3}{*}{2012} & 1 & 4 October-31 October & 1.07 & 1.07 & 1.07 \\
\hline & & & Average of $\Delta$ intAN(eddy) & 0.40 & 0.31 \\
\hline & & & standard deviation & 0.36 & 0.38 \\
\hline
\end{tabular}

${ }^{a}$ Cyclonic eddy with SSHA of about $-50 \mathrm{~cm}$

${ }^{\mathrm{b}}$ This period is in the deep winter mixing (DWM) period

(1) Slow sinking particle with sinking velocity of about $50 \mathrm{~m} \mathrm{day}^{-1}$ was reported based on measurement of particulate radiocesium emitted from the Fukushima Daiichi Nuclear Power Plant accident in March 2011 (Honda and Kawakami 2014), and

(2) When the surface ocean is well stratified and transparent, exopolymer particles (TEPs) are produced in this stratified layer by phytoplankton such as diatom (Mari 1999), coccolithophorids (Engel et al. 2004), and picophytoplankton, such as Prochlorococcus (Iuculano et al. 2017), TEPs, which is composed mainly of acidic polysaccharides and is sticky mucous, promoting the formation of marine aggregates (Passow et al. 2001). These aggregates are usually large, but loose and fluffy with low density and/or large drag, and therefore, might sink slowly or hardly at all (Bach et al. 2016). In late July when CE1 passed, KEO area was well stratified (surface mixed layer was about $20 \mathrm{~m}$ ). It is also suspected that Prochlorococcus is predominant in autumn in this area (Fujiki et al. 2014). In addition, slow sinking particles might not be always transported downward: their motion might sometimes be upward and sometimes lateral. If this is the case, the apparent sinking velocity would become very small. Likewise,

(3) Slow sinking velocity of settling particles observed in early October 2014 might also be supported by its lower density: concentration of "biogenic ballast" (sum of opal and $\mathrm{CaCO}_{3}$ concentrations), with density more than double that of organic matter $\left(\mathrm{CaCO}_{3}\right.$ 2.71; opal 2.10; organic matter $1.06 \mathrm{~g} \mathrm{~cm}^{-3}$, e.g., Klaas and Archer 2002), bringing particle to the ocean interior quickly (e.g., Klaas and Archer 2002; Francois et al. 2002; Honda and Watanabe 2010), was about $30 \%$ while that of settling particle observed in late December 2014-early January 2015 was about 60\%.

\section{Contribution of annual eddy-induced nutrient to annual carbon flux}

In addition, $\Delta_{\text {int }} \mathrm{AN}_{\text {(eddy) }}$ (annual $\Delta_{\text {int }} N_{\text {(eddy) }}$ ) reported here (Table 1) can be compared to previous annual 
carbon $(\mathrm{C})$ export studies at the western Pacific subtropical station $\mathrm{S} 1\left(30^{\circ} \mathrm{N} / 145^{\circ} \mathrm{E}\right.$, e.g., Honda et al. 2016, 2017), about 140 miles southeast of station KEO. Assuming $100 \%$ utilization of $\Delta_{\text {int }} \mathrm{AN}_{(\text {(eddy) }}$ and application of the Redfield ratio, $\Delta_{\text {int }} \mathrm{AN}_{(\text {eddy })}$-supported annual PP can be estimated to be $2.0-2.6$ mol- $C \mathrm{~m}^{-2}$ year $^{-1}$ (0.31-0.40 mol-N m ${ }^{-2}$ year $\left.^{-1} \times 6.6\right)$ (Table 2). At station S1, net primary production was observed to be 10.6 mol-C m${ }^{-2}$ year $^{-1}$ (Matsumoto et al. 2016; Honda et al. 2017). The $F$ ratio, which is the uptake ratio of nitrate (an externally-supplied nutrient) to the sum of this nitrate and ammonium (regenerated nutrient) and is comparable to the ratio of annual $\mathrm{C}$ export flux to net primary production, was estimated to be $\sim 0.3$ by the numerical simulation (Sasai et al. 2016). Thus, annual $C$ export flux or new production can be estimated to be $3.2 \mathrm{~mol}-\mathrm{C} \mathrm{m}^{-2}$ year $^{-1}(10.6 \times 0.3)$. Annual $\mathrm{C}$ export fluxes at 100 and $200 \mathrm{~m}$ at $\mathrm{S} 1$ were estimated to be 1.7 and 1.3 mol- $\mathrm{C} \mathrm{m}^{-2}$ year $^{-1}$, respectively, based on particulate organic carbon (POC) flux at respective depths observed by a drifting sediment trap (Honda et al. 2016). Sum of POC flux and dissolved organic carbon (DOC) flux at $200 \mathrm{~m}$ was also estimated from the carbon budget $\left(2.7 \mathrm{~mol}-\mathrm{C} \mathrm{\textrm {m } ^ { - 2 }}\right.$ year $^{-1}$ : Wakita et al. 2016). Thus, $\Delta_{\text {int }} \mathrm{AN}_{(\text {eddy) }}$-supported annual PP (2.0-2.6 mol-C $\mathrm{m}^{-2}$ year $\left.^{-1}\right)$ estimated in this study is comparable to the annual $\mathrm{C}$ export flux estimated from previous reports. As described earlier, aNCP at KEO was estimated to be $7 \pm 3$ mol- $\mathrm{C} \mathrm{m}^{-2}$ year $^{-1}$ using KEO buoy $\mathrm{pCO}_{2}$ and meteorological/physical oceanographic data (Fassbender et al. 2017). This value is slightly larger than our estimate and previous estimates. However, this might be reasonable because their aNCP was estimated for the surface mixed layer and, especially in summer, a portion of aNCP is likely to be regenerated in the upper layer $(<100 \mathrm{~m})$ and not exported to the ocean interior.

Thus $\Delta_{\text {int }} \mathrm{AN}_{\text {(eddy) }}$ estimated in this study was reasonable and it can be said that cyclonic eddies potentially play an important role in supplying nutrients to the oligotrophic upper layer and supporting much of the new production. However, our estimate is based on a simple numerical simulation without consideration of horizontal advection (i.e., efflux of nutrient from the eddy) and response rate of phytoplankton to temporal increase of nutrient (i.e., incomplete uptake). If efflux of nutrient and incomplete uptake had occurred, our estimate would have been overestimated. Inter-annual variability, which provides a measure of uncertainty to our interpretation of the annual average as a long-term mean, was also estimated to be about 100\% (Table 1). On the other hand, if cyclonic eddies originate from the subarctic eutrophic region, they may already possess enough nutrient without vertical mixing (e.g., Sasai et al. 2010). For a more complete understanding of how cyclonic eddy affect productivity, we would need to determine whether the eddy was a non-linear cyclonic eddy (Martin and Pondaven 2003), and if so, if it was a coherent Lagrangian vortex (Haller and Beron-Vera 2013). We would also need to consider various factors such as its birth place, its path, and its overall time at the fixed point (e.g., KEO).

\section{Effect of typhoon on physical oceanography and biogeochemistry}

During the experimental period (July 2014-June 2016), abrupt barometric pressure drops observed by the KEO

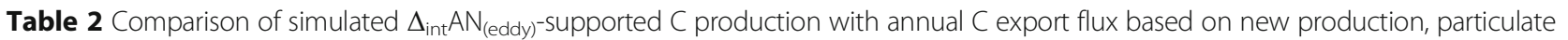
organic carbon (POC), and dissolved organic carbon (DOC) fluxes at station S1 and annual net community productivity (aNCP) in surface mixed layer at station KEO. POC flux at 100 and 200 m of station S1 were observed by seasonal drifting sediment trap deployment (Honda et al. 2016). Due to the many challenges of making sediment trap time-series from a mooring that extends into shallow water, for this KEO study, a deep sediment trap time-series mooring was used

\begin{tabular}{|c|c|c|}
\hline & mol-C $\mathrm{m}^{-2}$ year $^{-1}$ & References \\
\hline$\Delta_{\text {int }} \mathrm{AN}_{\text {(eddy) }}$-supported production ${ }^{\mathrm{a}}$ & $2.0-2.6$ & This study \\
\hline \multicolumn{3}{|l|}{ Annual N export flux based on: } \\
\hline New production at $\mathrm{S} 1^{\mathrm{b}}$ & 3.2 & $\begin{array}{l}\text { Matsumoto et al. (2016); } \\
\text { Honda et al. (2017); } \\
\text { Sasai et al. (2016) }\end{array}$ \\
\hline POC flux at $100 \mathrm{~m}$ of $\mathrm{S} 1$ & 1.7 & Honda et al. (2016) \\
\hline POC flux at $200 \mathrm{~m}$ of S1 & 1.3 & Honda et al. (2016) \\
\hline $\mathrm{POC}+\mathrm{DOC}$ flux at $200 \mathrm{~m}$ of $\mathrm{S} 1^{c}$ & 2.7 & Wakita et al. (2016) \\
\hline aNCP in surface mixed layer at KEO & $7 \pm 3$ & Fassbender et al. (2017) \\
\hline
\end{tabular}

${ }^{\mathrm{a}} \Delta_{\text {int }} \mathrm{AN}_{\text {(eddy) }}\left(0.31-0.40\right.$ mol-N m${ }^{-2}$ year $\left.^{-1}\right)$ multiplied by the Redfield ratio (6.6)

${ }^{b}$ Net primary productivity $\left(10.6\right.$ mol- $\mathrm{C} \mathrm{m}^{-2}$ year $\left.^{-1}\right)$ multiplied by $F$ ratio $(0.3)$

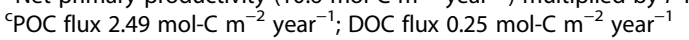


surface mooring indicate that three typhoons in 2014 (Typhoon S/N: T1414, T1417, T1420) and two typhoons in 2015 (T1514, T1516) passed near KEO (Additional file 4: Figure S3). Here, we consider the possibility of whether one of these typhoons triggered the enhanced biogenic materials' flux. As described in the "Introduction" section, previous studies have reported that typhoons can play a significant role in subsurface nutrient supply resulting in increase of PP. However, in contrast to previous reports (Lin 2012; Lin et al. 2003; Babin et al. 2004; Siswanto et al. 2007, 2008), no remarkable increase of surface Chl- $a$ during or after passage of these typhoons was observed (Fig. 2a). In addition, as can be seen in the profile time-series of seawater temperature (Fig. 5), large Ekman upwelling associated with the cyclonic winds, which could have supplied subsurface nutrient to the upper ocean, was also not evident.
On the other hand, it is notable that after typhoon T1414 passed, near-inertial internal waves occurred for about 10 days, with an inertial period of about $22 \mathrm{~h}$ and an amplitude of about $10 \mathrm{~m}$ in the upper seasonal pycnocline, i.e., around $50 \mathrm{~m}$ (Fig. 5a). Strong near-inertial oscillations could also be seen in the current meter at $36 \mathrm{~m}$ during T1414 (Additional file 5: Figure S4). Near-inertial internal waves are typically associated with vertical shears in horizontal velocity that can cause shear-instability mixing and enhanced diapycnal fluxes (Johnston et al. 2016, Inoue et al. 2017). Because this source of turbulent mixing within the euphotic zone extended for about 10 days, much longer than the duration of the passing typhoon, it is conceivable that this event could have provided a significant source of nutrients at a subsurface depth within the euphotic zone. If so, the turbulent mixing induced by typhoon passage might be responsible for

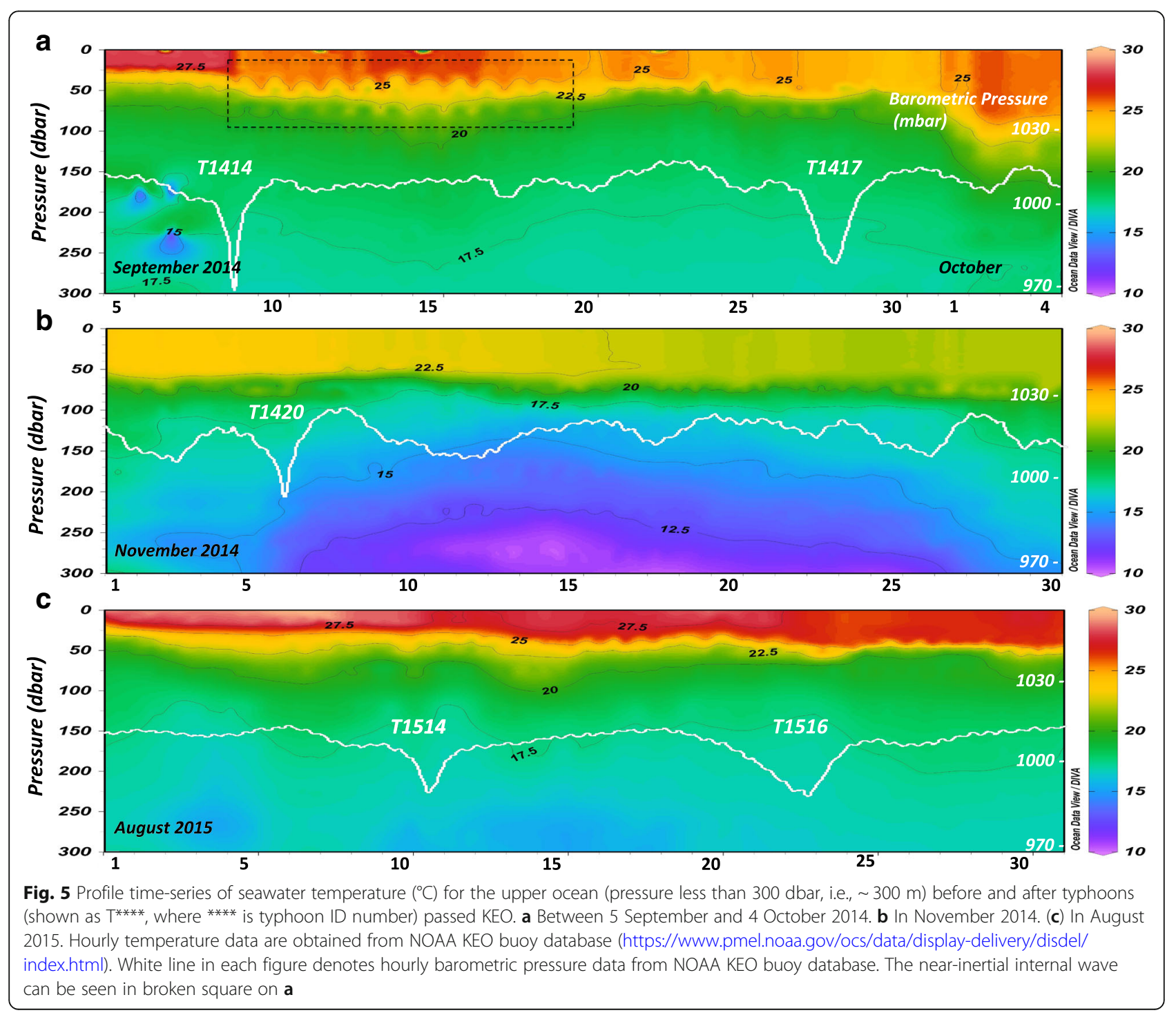


the increase of OCF observed by the sediment trap mooring in October.

To test this hypothesis, the turbulent flux of $\mathrm{NO}_{3}(\mathrm{~F})$ at thermocline or nitracline by turbulent mixing following typhoon T1414 was calculated according to

$$
F=\int_{t 1}^{t 2} \Delta K p(C / Z) d t
$$

where $\Delta K p$ is the increase in turbulent diffusivity (diffusion coefficient, $\left.\mathrm{m}^{2} \mathrm{~s}^{-1}\right)$ from an initial $K p\left(10^{-5} \mathrm{~m}^{2} \mathrm{~s}^{-1}\right.$ this study, see below) and $t 1$ and $t 2$ are the beginning and end of the mixing period. The $\mathrm{C} / \mathrm{Z}$ is $\mathrm{NO}_{3}$ concentration gradient (mmol- $\mathrm{N} \mathrm{m}^{-4}$ ). In this study, we suspected that $\mathrm{C} /$ $\mathrm{Z}$ in September between 50 and $100 \mathrm{~m}$ around KEO was $0.034 \mathrm{mmol} \mathrm{m}^{-4}$ based on climatological data (WOA2013: https://www.nodc.noaa.gov/cgi-bin/OC5/woa13/woa13oxnu.pl?parameter $=n$, Additional file 6: Figure S5) and model simulation (Fig. 4b). This concentration is comparable to that at station S1 (0.042 $\mathrm{mmol} \mathrm{m}^{-4}$ : Inoue et al. 2016).

Below the surface mixed layer in the KEO region, $K p$ has been reported to be $\sim 10^{-5} \mathrm{~m}^{2} \mathrm{~s}^{-1}$ (Mori et al. 2008; Nagai et al. 2009; Kaneko et al. 2012; Inoue et al. 2016,
2017), but is expected to increase significantly during and following a typhoon. In order to investigate change in diffusion coefficient $(\Delta K p)$ at $50-70 \mathrm{~m}$, where nitracline might exist (Additional file 6: Figure S5), a simple model simulation was conducted. Yablonsky and Ginis (2009) have shown that the cool SST wake following passage of typhoon is reproduced reasonably well by a one-dimensional model if the tropical cyclone translation speed is faster than $5 \mathrm{~m} \mathrm{~s}^{-1}$. Because this is generally the case in the KEO region, a one-dimensional model could help in understanding the effect of typhoons on nutrient fluxes into the euphotic zone and resulting ocean productivity. Time evolution of the vertical profiles of the horizontal component of velocity, temperature and salinity and turbulent kinetic energy was solved using a one-dimensional model based on Mellor-Yamada-Nakanishi-Niino scheme (Furuichi et al. 2012). The turbulence closure model computed the development of turbulent kinetic energy (TKE) as well as a set of length scales. The eddy diffusivity $\left(\mathrm{m}^{2} \mathrm{~s}^{-1}\right)$ is set by a length scale times the square root of TKE. The model was initialized using the vertical profiles of the horizontal component of velocity, temperature, and salinity as observed by the KEO buoy on 00Z 1 September
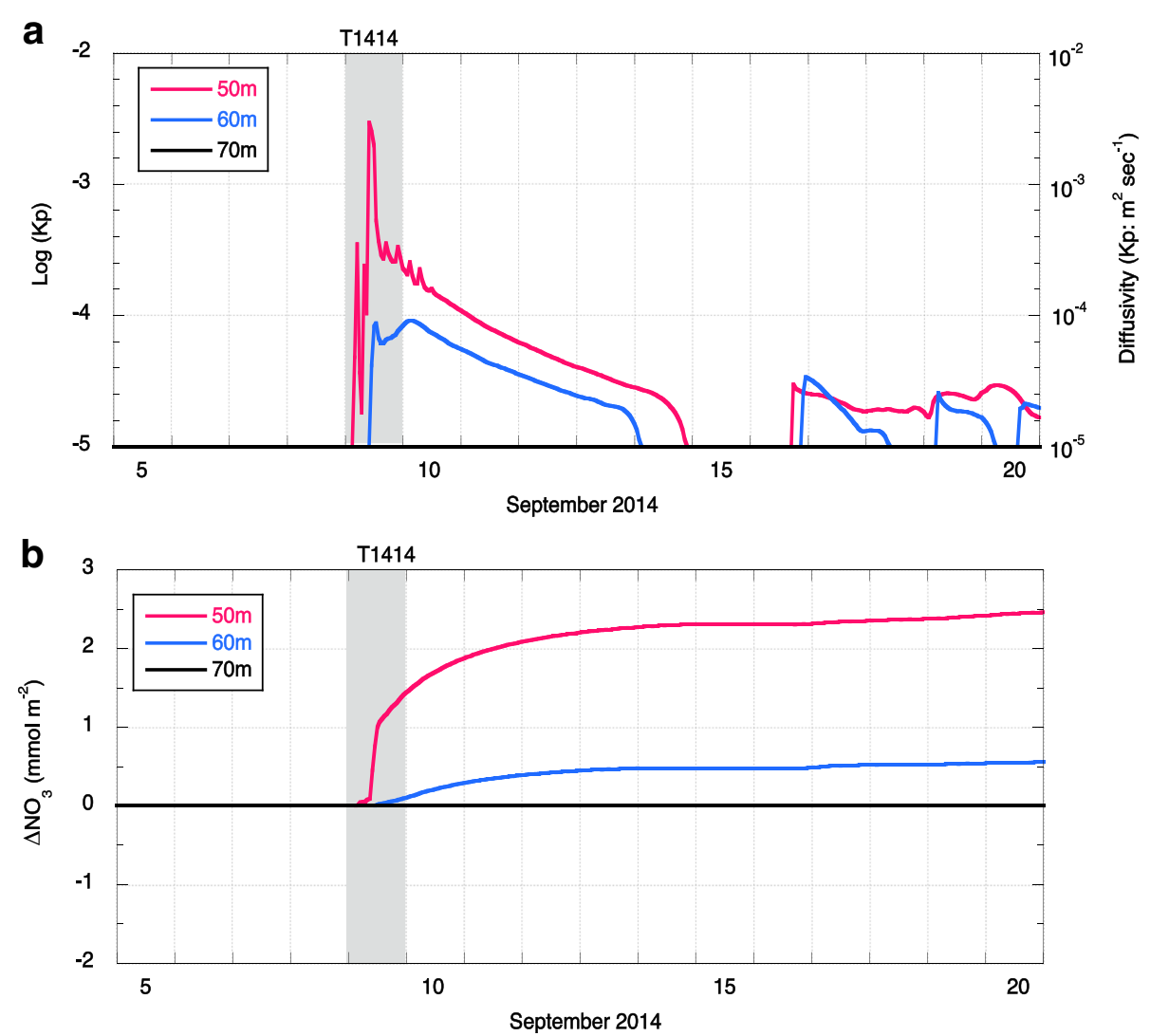

Fig. 6 a Time-series variability in simulated diffusion coefficient (Kp) at 50,60, and $70 \mathrm{~m}$ before and after typhoons T1414 pass near KEO in September 2014. b Integrated turbulent $\mathrm{NO}_{3}$ flux at 50, 60, and 70 m estimated using $\mathrm{Kp}$ (a) and concentration gradient (Additional file 6: Figure S5) 
2009 and integrated for 1 month using the atmospheric forcing dataset as provided by https://www.pmel.noaa.gov/ocs/KEO.

Before typhoon T1414 passed near KEO buoy (i.e., before 8 September 2014), initial $K p$ at 50-70 m was set to be $1 \times 10^{-5} \mathrm{~m}^{2} \mathrm{~s}^{-1}$ (Fig. 6a). After typhoon T1414 passed on 9 September, $K p$ at 50 and $60 \mathrm{~m}$ largely increased to $\sim 10^{-2.5} \mathrm{~m}^{2} \mathrm{~s}^{-1}$ and $\sim 10^{-4} \mathrm{~m}^{2} \mathrm{~s}^{-1}$, respectively. Thereafter, $K p$ at both depths decreased gradually and came back to initial coefficients $\left(10^{-5}\right)$ after 15 September. On the other hand, $K p$ at $70 \mathrm{~m}$ did not increase after T1414 pass. Thus, these estimated increases in $K p$ relative to the background values of $10^{-5} \mathrm{~m}^{2} \mathrm{~s}^{-1}(\Delta K p)$ caused by typhoon T1414, by Eq. (3) can be associated with integrated turbulent $\mathrm{NO}_{3}$ flux "F" of $\sim 2.4$ mmol-N m${ }^{-2}$ that could have supplied $\mathrm{NO}_{3}$ to the upper $50 \mathrm{~m}$ between 9 and 19 September (Fig. 6b). Following the same procedure used in the previous section ("Quantitative evaluation of individual cyclonic eddy as a nutrient supplier") for estimating the carbon flux supported by the eddy-induced $\mathrm{N}$ supply, the carbon flux supported by the typhoon-induced $\mathrm{N}$ supply was estimated. Doing so, we found that this typhoon-induced $\mathrm{N}$ supply could potentially introduce increases of PP of $\sim 158 \mathrm{mg}-\mathrm{C} \mathrm{m} \mathrm{m}^{-2}(2.4 \times 6.6 \times 12)$ and of $5000 \mathrm{~m}$ organic carbon flux (OCF) of $\sim 0.95 \mathrm{mg}-\mathrm{C} \mathrm{m}^{-2}$ $(158 \times 0.006)$. It is indicative that typhoon-induced $\mathrm{N}$ supply can support only $\sim 4 \%$ of observed increase of OCF in early October $\left(24.3 \mathrm{mg} \mathrm{m}^{-2}\right.$, see the "Quantitative evaluation of individual cyclonic eddy as a nutrient supplier" section). Thus, typhoon T1414 in early September 2014 did not contribute to OCF increase observed at $5000 \mathrm{~m}$ in early October. While typhoon is an intriguing potential mechanism for entraining nutrients into the euphotic zone, typhoon's significant role in nutrient supply was not observed in this study.

However, the above estimation was based on a climatological $\mathrm{NO}_{3}$ vertical profile with a large standard deviation because its $\mathrm{NO}_{3}$ data were collected from a broad area in the western Pacific subtropical region (Additional file 6: Figure S5). Seasonal observations of $\mathrm{NO}_{3}$ vertical profile, especially during the typhoon season, are needed at station KEO to more accurately determine typhoon effect on physical oceanography and biogeochemistry.

\section{Conclusions}

Time-series observation of settling particle from a sediment trap deployed adjacent to a surface buoy, instrumented for meteorology, physical oceanography, and biogeochemistry, revealed that cyclonic eddies are likely an important mechanism for nutrient supply. Unlike the spring bloom, which occurs after deep winter mixing brings nutrients to the surface, eddies tend to supply the nutrients to a level below the surface that is still in the euphotic zone. As a consequence, the resulting bloom occurs below the surface and is not apparent in satellite data. For this reason, we refer to this as a "missing nutrient source." Surprisingly, typhoons were not observed to play a significant role in the nutrient supply in this study. While we have focused on the supply of nutrients from deep winter mixing, eddies, and typhoons, other sources may also contribute. In particular, further work is needed to quantify the role of $\mathrm{N}_{2}$ fixation and eolian input for supplying nutrients in this oligotrophic ocean region.

\section{Additional files}

Additional file 1: Near-inertial internal wave. (DOCX $16 \mathrm{~kb}$ )

Additional file 2: Figure S1. SSHA around station KEO before, when and after the cyclonic eddy \#1 and \#2 (CE1 and CE2, respectively) passed over station KEO. (PDF $714 \mathrm{~kb}$ )

Additional file 3: Figure S2. Profile time-series of seawater temperature $\left({ }^{\circ} \mathrm{C}\right)$ in the upper ocean above $\sim 550 \mathrm{~m}$ at station KEO between 2008 and 2015. Figure is drawn with daily averaged data on KEO database website (https://www.pmel.noaa.gov/ocs/data/display-delivery/disdel/index.html). White line denotes temporal variability in satellite-based SSHA daily data. (PDF $1918 \mathrm{~kb}$ )

Additional file 4: Figure S3. Tracks of typhoons during experimental 2 years. Lines with open circle, square, triangle, plus, and cross are for typhoons T1414, T1417, T1420, T1514, and T1516, respectively. Numbers in figure are date and time of typhoon position. Data are obtained online from the website of the Japan Meteorology Agency (https://www.data.jm a.go.jp/fcd/yoho/typhoon/position_table/index.html). (PDF 41 kb)

Additional file 5: Figure S4. Hourly time-series of surface pressure ( $\mathrm{hPa}$, red line) and ocean current vector at $36 \mathrm{~m}$ depth ( $\mathrm{cm} \mathrm{s}^{-1}$, blue vector) at KEO for T1414, T1417, T1420, T1514, and T1516. (obtain from NOAA database). (PDF 86 kb)

Additional file 6 Figure S5. Vertical profile of $\mathrm{NO}_{3}$ in the subtropical region near KEO in September. Data of respective depths with standard deviation are obtained from WOA 2013 climatological database (red circles $30.5-34.5^{\circ} \mathrm{N} / 136.5-164.5^{\circ} \mathrm{E} ; n=11$ ) and from numerical model simulation (blue circles based on Fig. 4). The $\mathrm{NO}_{3}$ concentration gradient between 50 and $100 \mathrm{~m}$ is estimated to be $\sim 0.034 \mathrm{mmol} \mathrm{m}^{-4}$ using $0.3 \mu \mathrm{mol} \mathrm{kg} \mathrm{kg}^{-1}$ at $50 \mathrm{~m}$ and $2.0 \mu \mathrm{mol} \mathrm{kg} \mathrm{kg}^{-1}$ at $100 \mathrm{~m}$. (PDF $36 \mathrm{~kb}$ )

\section{Abbreviations}

BATS: Bermuda Atlantic Time-series Study; CAF: $\mathrm{CaCO}_{3}$ flux; CE: Cyclonic eddy; Chl-a: Chlorophyll-a concentration; DOC: Dissolved organic carbon; DWM: Deep winter mixing; JAMSTEC: Japan Agency for Marine-Earth Science and Technology; JRA25: Japanese 25-year reanalysis; KEO: Kuroshio Extension Observatory; LDR: Local deepening rate; NCP: Net community productivity; NIES: National Institute for Environmental Studies; NIW: Near-inertial internal waves; NOAA: National Ocean and Atmosphere Administration; NPZD: Nitrate-Phytoplankton-Zooplankton-Detritus; OCF: Organic carbon flux; OFES: Ocean general circulation model For the Earth Simulator; OPF: Biogenic opal flux; PMEL: Pacific Marine Environmental Laboratory; POC: Particulate organic carbon; PP: Primary productivity; SCM: Subsurface Chl-a maximum; SSHA: Sea surface height anomaly; SST: Sea surface temperature; TEPs: Transparent exopolymer particles; TKE: Turbulent kinetic energy; TMF: Total mass flux; WBCE: Western boundary current extension; WOA: World Ocean Atlas

\section{Acknowledgements}

We acknowledge Dr. Kazuhiko Matsumoto from JAMSTEC, Technicians from Marine Works Japan, and ship crews of RN Kaiyo, T/S Shinsei-maru, and MN Bluefin for the assistance of mooring work and data acquisition. Dr. Yutaka Yoshikawa from Kyoto University kindly provided opportunity to submit this paper to this journal (Progress in Earth and Planetary Science). The NOAA surface mooring is supported by the Ocean Observing and Monitoring Division, Climate Program Office, National Oceanic and Atmospheric 
Administration, US Department of Commerce. This is PMEL contribution 4643. OFES simulations were conducted on the Earth Simulator under the support of JAMSTEC. A part of this work was carried out by the joint research program of the Institute for Space-Earth Environmental Research (ISEE), Nagoya University. We deeply appreciate anonymous reviewers and the journal editor who provided constructive comments that helped improve this paper.

\section{Funding}

This study is financially supported by MEXT KAKENHI: grant-in-aid for scientific research in innovative areas JP15H05822, "Ocean Mixing Process; Impact on Biogeochemistry, Climate and Ecosystem" (URL: http://omix.aori.u-tokyo.ac.jp).

\section{Availability of data and materials}

Principal data analyzed during the current study are available at following online database:

Sediment trap data: https://ebcrpa.jamstec.go.jp/egcr/e/oal/oceansites_keo/ NOAA KEO buoy data: https://www.pmel.noaa.gov/ocs/data/disdel/

\section{Authors' contributions}

$\mathrm{MCH}$ designed this study and conducted time-series sediment trap experiment. YS was in charge of mathematical simulation. ES conducted satellite data analysis. AKY was in charge of analysis of typhoon and its impact on physical oceanography. MFC provided KEO buoy-derived meteorological/ physical oceanographic data and edits to the text. HA conducted mathematical simulation on time-series variability in turbulent diffusion. All authors read and approved the final manuscript.

\section{Competing interests}

The authors declare that they have no competing interests.

\section{Publisher's Note}

Springer Nature remains neutral with regard to jurisdictional claims in published maps and institutional affiliations.

\section{Author details}

'Japan Agency for Marine-Earth Science and Technology (JAMSTEC), Yokosuka, Kanagawa, Japan. ${ }^{2}$ Disaster Protection Research Institution, Kyoto University, Shirahama, Wakayama, Japan. ${ }^{3}$ Institute for Space-Earth Environmental Research, Nagoya University, Nagoya, Aichi, Japan. ${ }^{4}$ National Ocean and Atmosphere Administration (NOAA), Pacific Marine Environment Laboratory (PMEL), Seattle, WA, USA.

Received: 26 March 2018 Accepted: 12 July 2018

\section{Published online: 20 August 2018}

\section{References}

Babin SM, Carton JA, Dickey TD, Wiggert JD (2004) Satellite evidence of hurricane-induced phytoplankton blooms in an oceanic desert. J Geophys Res 109:1-21. https://doi.org/10.1029/2003JC001938

Bach LT, Boxhammer T, Larsen A, Hildebrandt N, Schulz KG, Riebesell U (2016) Influence of plankton community structure on the sinking velocity of marine aggregates. Glob Biogeochem Cycles 30:1145-1165. https://doi.org/10.1029/ 2016 GB005372

Bond NA, Cronin MF, Sabine C, Kawai Y, Ichikawa H, Freitag P, Ronnholm K (2011) Upper-ocean response to tyhpoon Choi-Wan as measured by the Kuroshio Extension Observatory (KEO) mooring. J Geophys Res 116(C02031). https:// doi.org/10.1029/2010JC006548

Bopp L, Resplandy L, Orr JC, Doney SC, Dunne JP, Gehlen M, Halloran P, Heinze C, Ilyina T, Seferian R, Tjiputra J, Vichi (2013) Multiple stressors of ocean ecosystems in the 21 century: projections with CMIP5 models. Biogeosciences 10:6225-6245. https://doi.org/10.5194/bg-10-6225-2013

Cronin MF, Bond NA, Farrar JT, Ichikawa H, Jayne SR, Kawai Y, Konda M, Qiu B, Rainville L, Tomita H (2013) Formation and erosion of the seasonal thermocline in the Kuroshio extension recirculation gyre. Deep-Sea Res II 85:62-74

Cronin MF, Meinig C, Sabine CL, Ichikawa H, Tomita H (2008) Surface mooring network in the Kuroshio extension. IEEE Syst Spec Issue GEOSS 2(3):424-430

Cronin MF, Pelland NA, Emerson SR, Crawford WR (2015) Estimating diffusivity from the mixed layer heat and salt balances in the North Pacific. J Geophys Res 120. https://doi.org/10.1002/2015JC011010

Duce RA, LaRoche J, Altieri K, Arrigo KR, Baker AR, Capone DG, Cornell S, Dentener F, Galloway J, Ganeshram RS, Geider RJ, Jickells T, Kuypers MM,
Langlois R, Liss PS, Liu SM, Middelburg JJ, Moore CM, Nickovic S, Oschlies A, Pedersen T, Prospero J, Schlitzer R, Seitzinger S, Sorensen LL, Uematsu M, Ulloa O, Voss M, Ward B, Zamora L (2008) Impacts of atmospheric anthropogenic nitrogen on the open ocean. Science 320:893-897

Engel A, Delille B, Jacquet $S$, Riebesell $U$, Rochelle-Newall $E$, Terbrüggen $A$ et al (2004) Transparent exopolymer particles and dissolved organic carbon production by Emiliania huxleyi exposed to different CO2 concentrations: a mesocosm experiment. Aquat Microb Ecol 34:93-104. https://doi.org/10. 3354/ame034093

Falkowski P, Zieman D, Kolber Z, Bienfang P (1991) Role of eddy-pumping in enhancing primary production in the ocean. Nature 352(55):55-55

Fassbender AJ, Sabines CL, Sutton AJ CMF (2017) Mixed-layer carbon cycling at the Kuroshio Extension Observatory. Glob Biogeochem Cycles 31. https://doi. org/10.1002/2016GB005547

Francois R, Honjo S, Krishfield MS (2002) Factors controlling the flux of organic carbon to the bathypelagic zone of the ocean. Glob Biogeochem Cycles 16(4):1087. https://doi.org/10.1029/2001GB001722

Fujiki T, Matsumoto K, Mino Y, Sasaoka K, Wakita M, Kawakami H, Honda MC, Watanabe S, Saino T (2014) Seasonal cycle of phytoplankton community structure and photophysiological state in the western subarctic gyre of the North Pacific. Limnol Oceanogr 59(1):887-900. https://doi.org/10.4310/lo.2014.59.0887

Fujiki T, Sasaoka K, Matsumoto K, Wakita M, Mino Y (2016) Seasonal variability of phytoplankton community structure in the subtropical western North Pacific. J Oceanogr 72:343-358. https://doi.org/10.1007/s10872-015-0346-9

Furuichi N, Hibiya T, Niwa Y (2012) Assessment of turbulence closure models for resonant inertial response in the oceanic mixed layer using a large eddy simulation model. J Oceanogr 68:285-294. https://doi.org/10.1007/s10872011-0095-3

Haller G, Beron-Vera FJ (2013) Coherent Lagrangian vortices: the black holes of turbulence. J Fluid Mech 731:R4. https://doi.org/10.1017/jfm.2013.391

Honda MC, Imai K, Nojiri Y, Hoshi F, Sugawara T, Kusakabe M (2002) The biological pump in the northwestern North Pacific based on fluxes and major components of particulate matter obtained by sediment trap experiments (1997-2000). Deep-Sea Res I| 49:5595-5625

Honda MC, Kawakami H (2014) Sinking velocity of particulate radiocesium in the northwestern North Pacific. Geophys Res Lett 41:3959-3965. https://doi.org/ 10.1002/2014GL060126

Honda MC, Kawakami H, Matsumoto K, Wakita M, Fujiki T, Mino Y, Sukigara C, Kobari T, Uchimiya M, Kaneko R, Saino T (2016) Comparison of sinking particles in the upper $200 \mathrm{~m}$ between subarctic station K2 and subtropical station S1 based on drifting sediment trap experiments. J Oceanogr 72:373-386. https:// doi.org/10.1007/s10872-015-0280-x

Honda MC, Kawakami H, Watanabe S, Saino T (2013) Concentration and vertical flux of Fukushima-derived radiocesium in sinking particles from two sites in the Northwestern Pacific Ocean. Biogeosciences 10:3525-3534

Honda MC, Matsumoto K, Fujiki T, Siswanto E, Sasaoka K, Kawakami H, Wakita M, Mino Y, Sukigara C, Kitamura M, Sasai Y, Smith SL, Hashioka T, Yoshikawa C, Kimoto K, Watanabe S, Kobari T, Nagata T, Hamasaki K, Kaneko R, Uchimiya M, Fukuda H, Abe O, Saino T (2017) Comparison of carbon cycle between the western Pacific subarctic and subtropical time-series stations: highlights of the K2S1 project. J Oceanogr 73:647-667. https://doi.org/10.1007/s10872-017-0423-3

Honda MC, Sasaoka K, Kawakami H, Matsumoto K, Watanabe S, Dickey TD (2009) Application of underwater optical data to estimation of primary productivity. Deep-Sea Res I 56:2281-2292

Honda MC, Watanabe S (2010) Importance of biogenic opal as ballast of particulate organic carbon (POC) transport and existence of mineral ballastassociated and residual POC in the Western Pacific Subarctic Gyre. Geophys Res Lett 37(L02605). https://doi.org/10.1029/2009GL041521

Inoue R, Honda MC, Fujiki T, Matsumoto K, Kouketsu S, Suga T, Saino T (2016) Western North Pacific integrated physical-biogeochemical ocean observation experiment (INBOX): part 2. Biogeochemical responses to eddies and typhoons revealed from the $\mathrm{S1}$ mooring and shipboard measurements. $J$ Mar Res 74:71-99

Inoue R, Kouketsu S (2016) Physical oceanographic conditions around the S1 mooring site. J Oceanogr 72:453-464. https://doi.org/10.1007/s10872-015-0342-0

Inoue R, Watanabe M, Osafune S (2017) Wind-induced mixing in the North Pacific. J Phys Oceanogr 47(7): 1587-1603. https://doi.org/10.1175/JPO-D16-0218.1

luculano F, Mazuecos IP, Reche I, Agustí S (2017) Prochlorococcus as a possible source for transparent exopolymer particles (TEP). Front Microbiol 8:709. https://doi.org/10.3389/fmicb.2017.00709 
Jickells TD, An ZS, Andersen KK, Baker AR, Bergametti G, Brooks N, Cao JJ, Boyd PW, Duce RA, Hunter KA, Kawahata H, Kubilay N, laRoche J, Liss PS, Mahowald N, Prospero JM, Ridgwell AJ, Tegen S, Torres R (2005) Global iron connections between desert dust, ocean biogeochemistry, and climate. Science 308:67-71

Johnston TMS, Chaudhuri D, Mathur M, Rudnick DL, Sengupta D, Simmons HL, Tandon A, Venkatesan R (2016) Decay mechanisms of near-inertial mixed layer oscillations in the Bay of Bengal. Oceanography 29(2):180-191 https:// doi.org/10.5670/oceanog.2016.50

Kaneko H, Yasuda I, Komatsu K, Itoh S (2012) Observations of the structure of turbulent mixing across the Kuroshio. Geophys Res Lett 39:L15602. https:// doi.org/10.1029/2012GL052419

Klaas C, Archer DE (2002) Association of sinking organic matter with various types of mineral ballast in the deep sea: implications for the rain ratio. Glob Biogeochem Cycles 16(4):1116. https://doi.org/10.1029/2001GB001765

Komori N, Takahashi K, Komine K, Motoi T, Zhang X, Segawa G (2005) Description of sea-ice compartment of coupled ocean-sea-ice model for the earth simulator (OIFES). J Earth Simul 4:31-45

Kouketsu S, Kaneko H, Okunishi T, Sasaoka K, Itoh S, Inoue R, Ueno H (2016) Mesoscale eddy effects on temporal variability of surface chlorophyll a in the Kuroshio extension. J Oceanogr 72:439-451. https://doi.org/10.1007/s10872-015-0286-4

Lin I-I (2012) Typhoon-induced phytoplankton blooms and primary productivity increase in the western North Pacific subtropical ocean. J Geophys Res 117(C03039). https://doi.org/10.1029/2011JC007626

Lin I-I, Liu WT, Wu CC, Wong GTF, Hu C, Chen Z, Liang WD, Yang Y, Liu KK (2003) New evidence for enhanced ocean primary production triggered by tropical cyclone. Geophys Res Lett 30:1718. https://doi.org/10.1029/2003GL017141

Mahadevan A, Thomas LN, Tandon A (2008) Comment on "eddy/wind interactions stimulate extraordinary midocean plankton bloom". Science 320(5875):448. http://science.sciencemag.org/content/320/5875/448.2

Mari X (1999) Carbon content and C:N ratio of transparent exopolymeric particles (TEP) produced by bubbling exudates of diatoms. Mar Ecol Prog Ser 183:5971. https://doi.org/10.3354/meps183059

Martin AP, Pondaven P (2003) On estimates for the vertical nitrate flux due to eddy pumping. J Geophys Res 108(C11):3359. https://doi.org/10.1029/2003JC001841

Masumoto Y, Sasaki H, Kagimoto T, Komori N, Ishida A, Sasai Y, Miyama T, Moto T, Mitsudera H, Takahashi K, Sakuma H (2004) A fifty-year-eddy-resolving simulation of the world ocean: preliminary outcomes of OFES (OGCM for the earth simulator). J Earth Simul 1:35-56

Matsumoto K, Abe O, Fujiki T, Sukigara C, Mino Y (2016) Primary productivity at the time-series statins in the northwestern Pacific Ocean. J Oceanogr 72:369371. https://doi.org/10.1007/s10872-016-0354-4

Matsumoto K, Honda MC, Sasaoka K, Wakita M, Kawakami H, Watanabe S (2014) Seasonal variability of primary production and phytoplankton biomass in the western Pacific subarctic gyre: control by light availability within the mixed layer. J Geophys Res Oceans 119(9):6523-6534. https://doi.org/10.1002/2014JC009982

McGillicuddy DJ Jr, Anderson LA, Bates NR, Bibby T, Buesseler KO, Carlson CA, Davis CS, Ewart C, Falkowski PG, Goldthwait SA, Hansell DA, Jenkins WJ, Johnson R, Kosnyrev VK, Ledwell JR, Li QP, Siegel DA, Steinberg DK (2007) Eddy/wind interactions stimulate extraordinary mid-ocean plankton blooms. Science 316:1021-1026

McGillicuddy DJ Jr, Robinson AR (1997) Eddy-induced nutrient supply and new production in the Sargasso Sea. Deep-Sea Res | 44:1427-1450

McGillicuddy DJ Jr, Robinson AR, Siegel DA, Jannasch HW, Johnson R, Dickey TD, McNeil J, Michaels AF, Knap AH (1998) Influence of mesoscale eddies on new production in the Sargasso Sea. Nature 394:263-265

Menkes CE, Lengaigne M, Levy C, Ethe L, Bopp O, Aumont E, Vincent J, Vialard J, Jullien S (2016) Global impact of tropical cyclones on primary production. Glob Biogeochem Cycles 30:767-786. https://doi.org/10.1002/2015GB005214

Mori K, Uehara K, Kameda T, Kakehi S (2008) Direct measurements of dissipation rate of turbulent kinetic energy of North Pacific subtropical mode water. Geophys Res Lett 35:L05601. https://doi.org/10.1029/2007GL032867

Nagai T, Tandon A, Yamazaki H, Doubell M (2009) Evidence of enhanced turbulent dissipation in the frontgenetic Kuroshio front thermocline. Geophys Res Lett 36:L12609. https://doi.org/10.1029/2009GL038832

Oka E, Qiu B, Takatani Y, Enyo K, Sasano D, Kosugi N, Ishii M, Nakano T, Suga T (2015) Decadal variability of subtropical mode water subduction and its impact on biogeochemistry. J Oceanogr 71(4):389-400. https://doi.org/10. 1007/s10872-015-0300-x

Onogi K, Tsutusi J, Koide H, Sakamoto M, Kobayashi S, Hatsushika H, Matsumoto T, Yamazaki N, Kamahori H, Takahashi K, Kadokura S, Wada K, Kato K, Oyama
R, Ose T, Mannoji N, Taira R (2007) The JRA-25 reanalysis. J Met Soc Jap 85: 369-432

Oschilies A (2001) Model-derived estimates of new production: new results point towards lower values. Deep-Sea Res II 48:2173-2197

Oschlies A (2002) Can eddies make ocean deserts bloom? Glob Biogeochem Cycles 16:1106. https://doi.org/10.1029/2001GB001830

Oschlies A, Garcon (1999) An eddy-permitting coupled physical-biological model of the North Atlantic 1. Sensitivity to advection numerics and mixed layer physics. Glob Biogeochem Cycles 13:135-160

Pan S, Shi J, Gao H, Guo X, Yao X, Gong X (2017) Contributions of physical and biogeochemical processes to phytoplankton biomass enhancement in the surface and subsurface layers during the passage of typhoon Damrey. J Geophys Res Biogeosci 122. https://doi.org/10.1002/2016JG003331

Passow U, Shipe RF, Murray A, Pak DK, Brzezinski MA, Alldredge AL (2001) The origin of transparent exopolymer particles (TEP) and their role in the sedimentation of particulate matter. Cont Shelf Res 21:327-346

Qiu B (2002) The Kuroshio extension system: its large-scale variability and role in mid latitude ocean-atmosphere interaction. J Oceanogr 58:57-75

Qiu B, Chen S, Schneider N, Taguchi B (2014) A coupled decadal prediction of the dynamic state of the Kuroshio extension system. J Clim 27:1751-1764. https://doi.org/10.1175/JCL-D-13-00318.1

Redfield AC, Ketchum BH, Richards FA (1963) The influence of organisms on the composition of seawater. In: Hill MN (ed) The sea, vol 2. Interscience, New York, pp 26-77

Rumyantseva A, Lucas N, Rippeth T, Martin A, Painter SC, Boyd TJ, Henson S (2015) Ocean nutrient pathways associated with the passage of a storm. Glob Biogeochem Cycles 29:1179-1189. https://doi.org/10.1002/2015GB005097

Sasai Y, Richards KJ, Ishida A, Sasaki H (2010) Effects of cyclonic mesoscale eddies on the marine ecosystem in the Kuroshio extension region using an eddyresolving coupled physical-biological model. Ocean Dyn 60:693-704. https:// doi.org/10.1007/s10236-010-0264-8

Sasai Y, Sasaki H, Sasaoka K, Ishida A, Yamanaka Y (2007) Marine ecosystem simulation in the eastern tropical Pacific with a global eddy resolving coupled physical-biological model. Geophys Res Lett 34(L23601). https://doi. org/10.1029/2007GL031507

Sasai Y, Yoshikawa C, Smith SL, Hashioka T, Matsumoto K, Wakita M, Sasaoka K, Honda MC (2016) Coupled 1-D physical-biological model study of phytoplankton production at two contrasting time-series stations in the western North Pacific. J Oceanogr 72:509-526. https://doi.org/10.1007/ s10872-015-0341-1

Schlitzer R (2003) Ocean data view, https://odv.awi.de

Shibano R, Yamanaka Y, Okada N, Chuda T, Suzuki S, Niino H, Toratani M (2011) Responses of marine ecosystem to typhoon passages in the western subtropical North Pacific. Geophys Res Lett 38(L18608). https://doi.org/10. 1029/2011GL048717

Siegel DA, McGillicuddy DJ, Fields EA (1999) Mesoscale eddies, satellite altimetry, and new production in the Sargasso Sea. J Geophys Res 104:13359-13379

Siswanto E, Ishizaka J, Morimoto A, Tanaka K, Okamura K, Kristijono A, Saino T (2008) Open physical and biogeochemical response to the passage of typhoon Meari in the East China Sea observed from Argo float and multiplatform satellites. Geophys Res Lett 35(L15604). https://doi.org/10.1029/2008GL035040

Siswanto E, Ishizaka J, Yokouchi K, Tanaka K, Tan CK (2007) Estimation of interannual and interdecadal variations of typhoon-induced primary production: a case study for the outer shelf of the East China Sea. Geophys Res Lett 34(L03604). https://doi.org/10.1029/2006GL028368

Sukigara C, Suga T, Toyama K, Oka E (2014) Biogeochemical responses associated with the passage of a cyclonic eddy based on shipboard observations in the western North Pacific. J Oceanogr 70:435-445. https://doi.org/10.1007/ s10872-014-0244-6

Sweeney EN, McGillicuddy DJ Jr, Buesseler KO (2003) Biogeochemical impacts due to mesoscale eddy activity in the Sargasso Sea measured at the Bermuda Atlantic Time-Series Study (BATS). Deep-Sea Res II 50:3017-3039

Taylor SR (1964) Abundance of chemical elements in the continental crust: a new table. Geochim Cosmochim Acta 28:1273-1285

Tomita H, Kako S, Cronin MF, Kubota M (2010) Preconditioning of the wintertime mixed layer at the Kuroshio Extension Observatory. J Geophys Res 115(C12053). https://doi.org/10.1029/2010JC006373

Wakita M, Honda MC, Matsumoto K, Fujiki T, Kawakami H, Yasunaka S, Sasai Y, Sukigara C, Uchimiya M, Kitamura M, Kobari T, Mino Y, Nagano A, Watanabe S, Saino T (2016) Biological organic carbon export estimated from the annual carbon budget observed in the surface waters of the western subarctic and 
subtropical North Pacific Ocean from 2004 to 2013. J Oceanogr 72(5):665685. https://doi.org/10.1007/s10872-016-0379-8

Yablonsky R, Ginis I (2009) Limitation of one-dimensional ocean models for coupled hurricane-ocean model forecasts. Mon Weather Rev 137:4410-4419. https://doi.org/10.1175/2009MWR2863.1

Zhang S, Xie L, Hou Y, Zhao H, Qi Y, Yi X (2014) Tropical storm-induced turbulent mixing and chlorophyll-a enhancement in the continental shelf southeast of Hainan Island. J Mar Syst 129:405-414. https://doi.org/10.1016/j.jmarsys.2013. 09.002

Submit your manuscript to a SpringerOpen ${ }^{\circ}$ journal and benefit from:

- Convenient online submission

- Rigorous peer review

- Open access: articles freely available online

High visibility within the field

- Retaining the copyright to your article

Submit your next manuscript at $\boldsymbol{\nabla}$ springeropen.com 